\title{
RECENT Judicial DeVELOPMENTS OF INTEREST TO OIL AND GAS LAWYERS
}

\author{
Geoffrey D. Baker" and Catherne A. Crang ${ }^{*}$
}

This article is a compilation of recent Canadian decisions of interest to oil and gas lawyers. The authors discuss a variety of cases in areas such as lands, leases and tilles, administrative law, contracts, torts, the environment, tax and royalties.
Le présent article est une compilation des décisions canadiennes récentes destinée anx avocats oeuvrant dans les secteurs pétrolier et gazier. Les auteurs examinent divers cas dans des diffërents domaines - baux et titres, droit administratif. contrats, délits, environnement, laxes et redevances.

\section{TABLE OF CONTENTS}

I. INTRODUCTION .................... 440

II. ABORIGNAL RIGHTS $\ldots \ldots \ldots \ldots \ldots \ldots \ldots \ldots \ldots \ldots 41$

A. DELGAMUUKW v. BRITISH COLUMBIA ............ 441

B. CHEVRON CANADA RESOURCES V. CANADA (EXECUTIVE

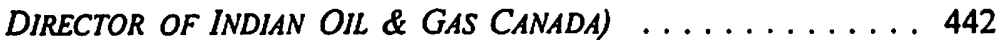

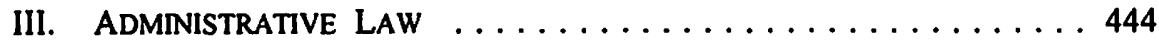

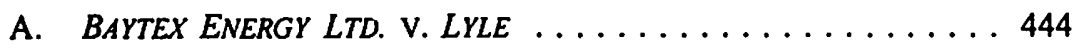

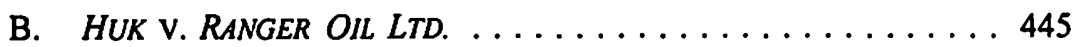

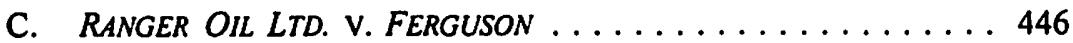

D. JOHNSTON V. ALBERTA

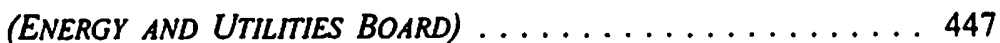

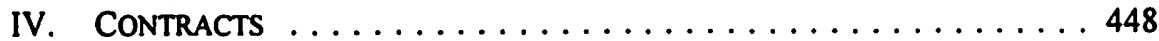

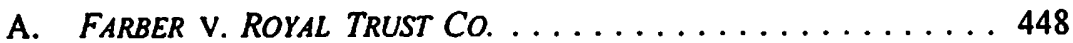

B. GLIMMER RESOURCES INC. V. EXALL RESOURCES LTD. . . . 450

C. BRINKERHOFF INTERNATIONAL INC.

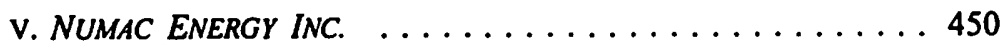

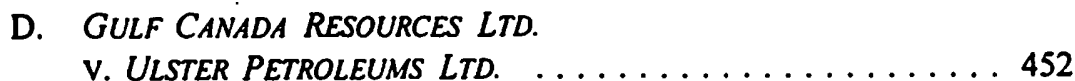

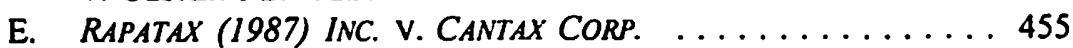

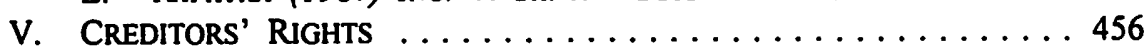

A. BANK OF MONTREAL v. DYNEX PETROLEUM LTD. . . . . . 456

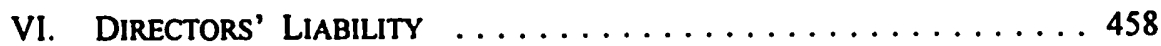

A. NORMART MANAGEMENT LTD.

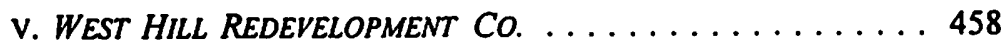

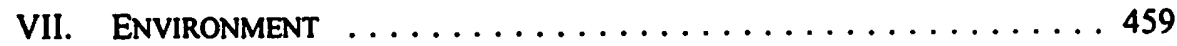

A. LABRADOR INUIT ASSN. V. NEWFOUNDLAND

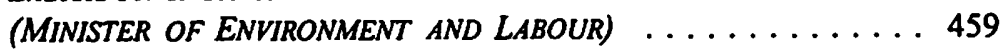

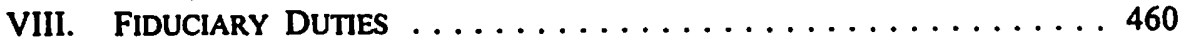

A. GULF CANADA RESOURCES LTD.

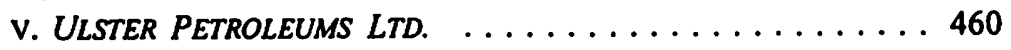

-. Associate, Carscallen Lockwood Cormie, Calgary, Alberta. 
B. MOCO RESOURCES LTD.

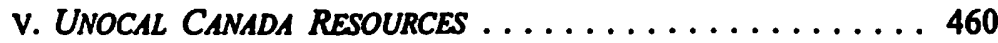

IX. LANDS, LEASES AND TITLES $\ldots \ldots \ldots \ldots \ldots \ldots \ldots \ldots$. 461

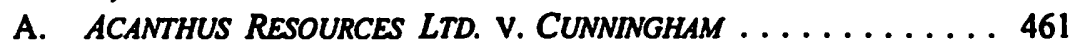

B. HILL V. NOVA SCOTIA (ATTORNEY GENERAL) ......... 462

C. CanAdLAN CRUde SEPARATORS INC. v. MYCHaLUK ....... 463

D. MCDONELL ESTATE V. SCOTT WORLD WIDE INC. ........ 465

X. LEAVE to APPEAL to the SUPREME Court of CANADA ..... 467

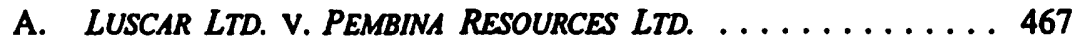

B. UNTTED STATES v. IVEY . . . . . . . . . . . . . . . 467

C. ALBERTA WILDERNESS ASSOCLATION

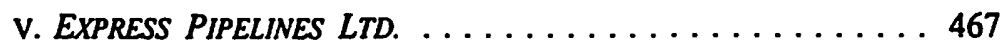

D. ROBERT LEMMONS \& ASSOCIATES

v. GANNON BROS. ENERGY LTD. . . . . . . . . . . . 467

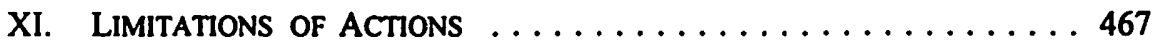

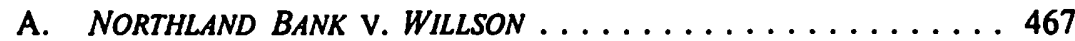

B. 602533 ONTARIO INC. v. SHELL CANADA LTD. . . . . . . 468

XII. Practice .......................... 469

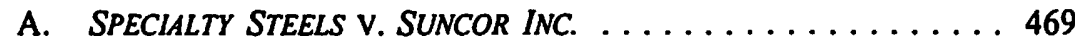

B. ANDERSON EXPLORATION LTD.

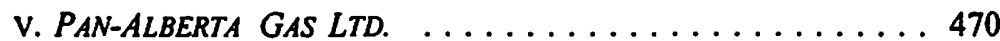

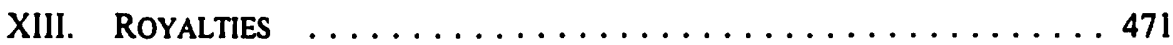

A. ACANTHUS RESOURCES LTD. V. CUNNINGHAM ........ 471

B. IMPERIAL OIL RESOURCES LTD. V. CANADA (MINISTER

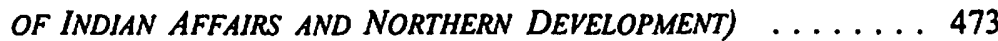

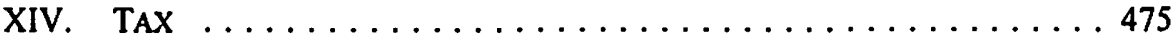

A. IKEA LTD. v. CANADA, TORONTO COLLEGE PARK LTD.

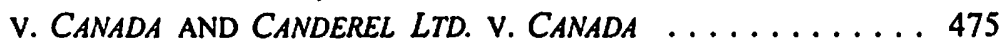

XV. TORTS .......................... 476

A. HERCULES MANAGEMENTS LTD. V. ERNST \& YOUNG ..... 476

B. BOW VALLEY HUSKY (BERMUDA) LTD.

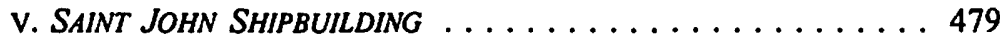

C. NORMART MANAGEMENT LTD.

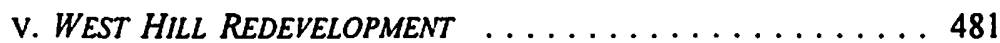

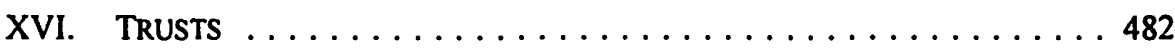

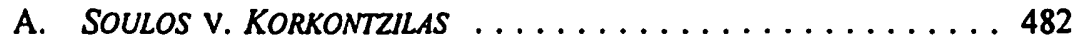

\section{INTRODUCTION}

This article covers a number of Canadian decisions released between January 1997 and April 1998. During this period there have been numerous decisions in various areas of law which lawyers practicing in the oil and gas area will find important. The authors have placed emphasis on those decisions which, in their opinion, are of greatest significance to these lawyers. Due to the large number of cases, the decisions covered in this article are neither a complete list of all the relevant cases, nor is each case a complete brief of the issues in the case. The case summaries and comments outlined herein should not be relied on in place of the reader's review of the decisions 
themselves and should not be relied on as legal advice. Further, the opinions expressed herein are those of the writers only and not of Carscallen Lockwood Cormie.

\section{AbORiginal RightS}

\section{A. DELGAMUUKW V. BRITISH COLUMBiA'}

\section{FACTS}

This case arose under claims by the Gitksan and Wet'suwet'en peoples for ownership and jurisdiction over certain lands located in British Columbia. By the time the case had advanced to the Supreme Court of Canada level, the arguments were focused upon not only ownership of the Territories, but self-government. Because the pleadings did not provide a satisfactory framework for the determination of the self-govermment question, and because the Supreme Court of Canada found that the trial judge had not dealt appropriately with a significant portion of the evidence (and in particular the oral histories advanced by the plaintiffs), the matter was referred back for a new trial. However, the court did set out a number of guidelines to be used in considering such claims in the future.

\section{DECISION}

The main points set out by the Supreme Court of Canada are as follows:

(1) aboriginal title encompasses the right to exclusive use and occupation of the land even if the use is not related to traditional aboriginal practices;

(2) the uses to which the land is put must not be irreconcilable with the nature of the group's attachment to the land;

(3) aboriginal title is sui generis (unique) and therefore distinguished from other proprietary interests;

(4) aboriginal title to lands is inalienable and cannot be transferred, sold or surrendered to anyone other than the Crown;

(5) aboriginal title encompasses mineral rights and the minerals are capable of exploitation, even though such use is not a traditional one;

(6) if aboriginal peoples wish to use their lands in a way that aboriginal title does not permit, then they must surrender those lands and convert them into nontitle lands to do so;

(7) aboriginal rights can encompass rights to certain practices, customs and traditions where the activity is not sufficient to support a claim to title to the 
land (the Court cites specific rights to engage in particular activities on particular lands);

(8) in order to establish a claim to aboriginal title, the group asserting the claim must establish that it occupied the lands in question at the time at which the Crown asserted sovereignty over the lands subject to the title;

(9) evidence of pre-sovereignty occupation may be difficult and, accordingly, an aboriginal community may provide evidence of present occupation as proof of pre-sovereignty occupation in support of a claim to aboriginal title;

(10) at sovereignty, occupation must have been exclusive;

(11) constitutionally recognized aboriginal rights are not absolute and may be infringed by the federal and provincial governments if the infringement (1) furthers a compelling and substantial legislative objective; and (2) is consistent with the special fiduciary relationship between the Crown and the aboriginal peoples;

(12) fair compensation will ordinarily be required when aboriginal title is infringed;

(13) provincial laws of general application cannot extinguish aboriginal rights; and

(14) provincial laws of general application can apply to "Indians" by virtue of s. 88 of the Indian Act. ${ }^{2}$

\section{COMMENTS}

While the case does. not deal directly with oil and gas issues, it makes very interesting reading and provides a further indication of the approach that the Supreme Court of Canada is taking to the characterization and proof of aboriginal rights. It is also interesting to note that the court encouraged the parties to enter into negotiations to resolve the claims without the necessity of further litigation and, in particular, reminded the Crown of its fiduciary duties toward the aboriginal peoples.

\section{B. Chevron Canada Resources v. Canada} (EXECUTIVE DIRECTOR OF INDIAN OIL \& GAS CANADA) ${ }^{3}$

\section{FACTS}

Chevron Canada Resources ("Chevron") claimed that it had overpaid royalties from 1991 to 1996 totalling over $\$ 9,000,000$. The payments had been made to the Crown in Right of Canada and received by it in trust for the bands which owned the mineral rights. It applied for an order permitting it to pay royalties into a trust account pending 
final determination of the action. In a side issue, the Indian bands claimed that some of the material filed by Chevron was improperly presented, as it was "without prejudice" communications which formed part of settlement negotiations.

\section{DECISION}

The Alberta Court of Appeal held that although the court has jurisdiction to order a pre-judgment remedy in the appropriate circumstances, this was not a case where the pre-judgment remedy should be granted. The court held that Chevron was not entitled to a legal set-off, as the "debt" which Chevron claimed was denied by the defendant. The Court also reviewed the requirements for equitable set-off (at 164) and determined that equitable set-off was not available because Chevron could not show any equitable ground entitling it to be protected against its adversary's demands, which equitable ground would go to the very root of the plaintiff's claim.

Notwithstanding that Chevron attempted to characterize the remedy as a preservation of its right of set-off, the court accepted the defendant's argument that it was merely allowing the plaintiff to build up a fund to cover any future judgment debts that might be awarded to it. The Court found that this amounted to extraordinary relief and, relying upon the Supreme Court of Canada decision in Aetna Financial Services Ltd. v. Feigelman," that "execution cannot be obtained prior to judgment and judgment cannot be recovered before a trial."

In particular, the court held that there is a very high onus on a plaintiff seeking such extraordinary relief. The onus is not met in the absence of proof that the defendant plans to deal with its assets fraudulently or for an improper purpose.

Chevron argued that denying the application would prejudice its rights because the Indian oil and gas royalty scheme prevented it from exercising the rights it would have if it were dealing with another private party including, for example, set-off and garnishment. Chevron felt it must make the payments or risk being held in default of the lease for failing to make the payments in the required manner. The court acknowledged that the scheme established by the Indian Act and the Indian Oil and Gas $\mathrm{Act}^{6}$ (and the relevant regulations under each) made it clear that payments of Indian oil and gas royalties are not comparable to payments of non-Indian oil and gas royalties. The court declined to decide whether the comprehensive scheme established by Parliament to regulate Indian oil and gas royalties precludes the use of ordinary remedies which would apply between private parties in Alberta in alleged overpayment situations. The court found that it was inappropriate to attempt such determination where the merits of the underlying action are so contentiously disputed. A further factor in the consideration was that the very payments which were sought to be held in the trust account might be inexigible and not available to satisfy any judgments which might be rendered only against the bands at the end of the day. 


\section{COMMENTS}

The case highlights the fact that operations on aboriginal lands involve factors not found in ordinary commercial relations and that the courts will not be quick to intervene to annul those differences.

\section{ADMINISTRATIVE LAW}

\section{A. BAYTEX ENERGY LTD. V. LYLE \\ 1. FACTS}

The Alberta Surface Rights Board (the "Board") found that a pattern of negotiated agreements entered into between oil companies and landowners in the subject area could not be used exclusively in determining the value of compensation to be paid to landowners for disturbance caused by granting rights of entry to an operator. At the hearing the operator provided evidence that there had been a "pattern of agreements" in the area providing for compensation of $\$ 700$ per acre. The landowners provided evidence of other sales in the area which suggested a higher value than this. The Board departed from the pattern of agreements and issued a greater award. The operator appealed.

\section{DECISION}

The court held that, generally, the pattern of agreements entered into between operators and landowners in the subject area is the best indication of the appropriate compensation to be paid to the land owners. The compensation was set at $\$ 700$ per acre. The court was of the view that, had the same in-depth evidence presented on the appeal been presented to the Board, it would have come to the same decision as the court.

\section{COMMENTS}

It is appropriate to use a "pattern of dealings" in determining compensation to landowners unless there is good reason to depart from that pattern. 


\section{B. HUK V. RANGER OIL LTD. ${ }^{8}$}

\section{FACTS}

In January 1995, the appellants granted a permit to the respondent to conduct certain geophysical operations on the appellants' land. The operations were carried out over the next few months. In the appellants' view, the operations were causing more damage to the land than the permit had contemplated. In April 1995, the appellants applied for mediation and arbitration to settle the matter of compensation pursuant to $s$. 16 of the British Columbia Petroleum and Natural Gas Act. ${ }^{9}$ The respondent questioned whether the Mediation and Arbitration Board (the "Board") had jurisdiction under the Act. In July 1995, the Board determined that it had jurisdiction. The Board then stated a case for consideration by the British Columbia Supreme Court pursuant to ss. 24(2) of the Act. The court held that the Board did not have the power to assess and compensate for damages caused by geophysical exploration. The appellants appealed.

\section{DECISION}

The British Columbia Court of Appeal held that the scheme of the Act is to set up a claim process for the handling of disputes which may arise between landowners and operators in the industry. It would not be appropriate for a claim of this nature to fall outside the jurisdiction of the Board. Paragraph 9(2)(a) of the Act provided that a person who enters or uses land to explore for petroleum is liable to pay compensation to the landowner for damage caused to the land up to the date stated in the certificate of restoration. However, ss. 9(3) provided that paragraph 9(2)(a) did not apply to geophysical exploration. The court found that paragraph 9(2)(a) merely eliminated the requirement of the need for a certificate of restoration for a landowner to claim damages for geophysical exploration. Accordingly, the court determined that the amendment actually confirmed the basic intent of the legislative scheme, which was to provide a system or code for these type of disputes. The court remitted the matter to the Board for determination on the merits.

\section{COMMENTS}

This case demonstrates the court's deference to administrative boards to determine matters within their sphere of expertise and to take a broad view of a board's enabling jurisdiction. 


\section{RANGER OIL LTD. V. FERGUSON 10 \\ 1. FACTS}

The appellant, Ranger Oil Ltd. ("Ranger"), obtained fourteen right-of-entry orders from the Alberta Land Compensation Board (the "Board") as to lands owned by the respondent owners. The owners appealed the compensation award as to adverse effect and general disturbance to the Court of Queen's Bench where, under the Alberta Surface Rights Act, ${ }^{1}$ the appeal was in the form of a new hearing. The grounds of the appeal were that the Board had failed to give any consideration to a discernible "pattern of dealings" present within the general area between the owners and operators, which had resulted in significantly higher negotiated settlements than the amounts awarded by the Board. In the new hearing, the trial judge received evidence from the owners' expert concerning the pattern of dealings in the area. Relying upon this evidence, the trial judge increased the amounts that had been ordered by the Board as to general disturbance and adverse effect.

Ranger appealed to the Court of Appeal. Ranger argued that the trial judge erred in accepting the opinions of the owners' expert in the absence of any direct evidence of the underlying transactions upon which his opinions were based. It also argued that the trial judge erred in admitting evidence of compensation negotiated after the dates of the right-of-entry orders.

\section{DECISION}

The Court of Appeal held that the trial judge did not err in either regard and dismissed the appeal. The evidence of the expert was admissible, notwithstanding that some of the documents were not put before the court and none of the landowners were called as witnesses. Its reliability was never called into question. The facts relied upon by the expert witness were derived from documents that he had personally examined, and he had followed professional practice in preparing his report. Moreover, if Ranger had concerns about the reliability of the evidence concerning other documents, it could have taken steps to introduce those documents into evidence as well, which it had not done.

The court also noted that there were strong policy reasons why, in a hearing concerning compensation for surface rights, it should not generally be necessary to put before the court or the Board all leases and related documents upon which an expert has relied or the testimony of all the individuals who were parties to those documents. In many cases this would add exponentially to the length and cost of the hearing.

With respect to the use of evidence of compensation negotiated after the right-ofentry orders, the court held that there was no reviewable error in this regard. First, it was not apparent that the trial judge placed any reliance on this evidence and, if he had, 
it could only be inferred from the decision that the trial judge attached little weight to this material. Even if the trial judge admitted inadmissible evidence, that evidence did not affect his decision and there was no ground for appellate review. Furthermore, the operator had also put into evidence material that post-dated the entry. Finally, the court noted that ss. 25(1) of the Surface Rights Act is worded permissively and expressly allows the Board to consider "any other factors that the Board considers proper under the circumstances." However, the court indicated that it may be inappropriate in other cases to take post-entry evidence into account.

\section{COMMENTS}

This decision demonstrates that courts accept that there are less stringent rules placed on administrative boards in terms of procedural and evidentiary matters. In practical terms, the key aspect of this decision is the court's conclusion that it is generally not necessary to submit into evidence all of the leases and related documents upon which an expert has relied or the testimony of all the individuals who were parties to those documents in these types of compensation hearings.

As well, this case may seem at odds with $H u k,{ }^{12}$ outlined above. The difference between the two cases may fall to the fact that in Ferguson the appeal under the Alberta Surface Rights Act was in the form of a new hearing. In Huk the British Columbia Mediation and Arbitration Board stated a case for consideration by the British Columbia Supreme Court under ss. 24(2) of the Petroleum and Natural Gas Act. ${ }^{13}$ There is no reference in the case to this being in the form of a new hearing.

\section{JOHNSTON V. ALBERTA (ENERGY AND UTILITIES BOARD) ${ }^{14}$ \\ 1. FACTS}

This case arises out of Shell Canada Ltd.'s ("Shell's") application to increase the volume of gas processed at its Caroline, Alberta sour gas plant. The Energy and Utilities Board (the "Board") approved Shell's application subject to certain conditions. The plaintiffs/applicants applied for leave to appeal the decision. The application for leave to appeal was based upon errors in jurisdiction or law and errors in findings of fact. The Board permitted the applicants to participate in the hearing and then later denied them status as intervenors.

\section{DECISION}

The Court of Appeal held that notwithstanding the denial of status as intervenors, the applicants had had the opportunity to participate in the hearing and, accordingly, that the decision of the Board was not affected one way or another. The applicants also argued that the Board had failed to consider the evidence adduced by them. The Court 
of Appeal held that there was no necessity for the Board to address in detail in its decision all of the evidence put before it and it was clear from the Board's reasons that it was alive to the various issues that the applicants were advancing.

The third argument advanced by the applicants was that the Board based its decision, at least in part, on evidence that was not before it at the hearing. In particular, the applicants complained that the Board had taken into account certain studies and policy reviews underway at the Board. The court held that commenting on the reports was not the same as relying upon them and that the plain wording of the Board's decision makes it clear that, in the main, this evidence was not relied upon in allowing Shell's application.

The applicants also argued that the Board had erred in not taking into account the report of the Alberta Environment Centre entitled "Cattle and the Oil and Gas Industry." The Court held that there were two responses to this argument. The first was that the Board was not obligated to consider evidence regarding the effect of flare pollutants on cattle and therefore not obliged to consider the report itself. Secondly, the Board had determined at a pre-hearing meeting that it would limit the scope of the hearing and hear evidence only as to the possible effects of increased gas production and would not hear evidence related to cattle health. That limitation had been upheld by a previous decision of the Alberta Court of Appeal. ${ }^{15}$

The court also held that it will not interfere with the Board's findings where there is some evidence to support them, or where the findings cannot be said to be patently unreasonable. The court found that given the evidence adduced at the hearing, there was no basis for the court to refuse to apply the findings in this case.

\section{COMMENTS}

This case further confirms the pattern of deference to administrative boards and the practical approach to be taken in reviewing their decisions.

\section{CONTRacts}

\section{A. FARBER V. ROYAL TRUST CO. ${ }^{16}$ \\ 1. FACTS}

Farber was the regional manager of western Quebec for Royal Trust. He brought an action for wrongful dismissal on the basis that Royal Trust had constructively dismissed him when, after eliminating his position as part of a corporate restructuring, it offered him a branch manager's position and some financial compensation (a $\$ 40,000$ reorientation allowance payable over two years and an 8.75 percent override 
commission on the net commissions from the agents at the branch). The regional manager's position had a guaranteed salary plus commissions, but the branch manager's salary was based solely on commissions. The trial judge dismissed Farber's action and found that Royal Trust's offer was reasonable in light of the commissions that Farber would have earned if he had accepted the employment offer. The Court of Appeal upheld that decision and Farber appealed to the Supreme Court of Canada. The issue was whether Farber was constructively dismissed and, if so, what damages should be awarded to him.

\section{DECISION}

The Supreme Court of Canada allowed the appeal and held that under article 1670 of the Civil Code of Quebec general contractual principles applied to employment contracts. Where an employer decides unilaterally to make substantial changes to the essential terms of an employment contract and the employee does not agree to the changes and leaves his or her job, the employee has not resigned, but has been dismissed. On the other hand, an employer can make changes to an employee's position where it is allowed by the contract. The extent of the employer's discretion to make changes will depend upon the agreement of the parties when they entered into the contract.

In this case, a reasonable person in the same situation as the employee would have concluded that the change Royal Trust imposed on Farber through its offer altered the essential terms of the employment contract. Farber was demoted with a considerable loss of status and prestige. In addition, his remuneration was reduced.

Royal Trust argued that its offer did not result in a change to the salary terms of Farber's employment because the sales figures from the branch were markedly higher than what was expected and had Farber accepted the position he would have in fact earned more than if he had remained a regional manager. The court held that subsequent sales figures from the branch were not admissible because they were not relevant in determining whether the employment contract had been breached at the time that Farber was offered a new position. The subsequent sales figures could not be reasonably foreseen at the time of the offer. One year's remuneration in lieu of notice was reasonable.

\section{COMMENTS}

This case is simply an affirmation of general employment contract principles. It shows the difficulty employers face when undergoing corporate restructuring that eliminates certain positions. Either the employment contract must allow for changes to be made to the employee's position, or comparable employment must be offered to the employee. Otherwise, reasonable notice, or compensation in lieu thereof, must be extended to the employee. 


\section{B. GLIMMER RESOURCES INC, V. EXALL RESOURCES LTD. ${ }^{17}$ \\ 1. FACTS}

Exall Resources Ltd. ("Exall") applied for an order that an issuance of shares by Glimmer Resources Inc. ("Glimmer") and the sale of such shares by Glimmer to a third party violated a joint venture agreement between Exall and Glimmer, which granted Exall a right of first refusal ("ROFR"). Exall owned a 60 percent interest in the joint venture. George Kent, the controlling shareholder of Glimmer, also transferred his shares in Glimmer to the third party. Kent was not a party to the joint venture agreement that gave Exall the ROFR. As a result of these transfers, the third party acquired control of Glimmer.

\section{DECISION}

The court dismissed Exall's application and granted Glimmer a declaration that the transaction was not subject to Exall's ROFR. The ROFR clause referred only to assigning, selling or otherwise transferring the interest in the joint venture project. What was done in this case was not such a transfer, assignment or sale of any interest in the project. The share transfer did not change the ownership of Glimmer's interest in the project, since it remained the owner of its share of the joint venture. The joint venture agreement was not intended to cover a transfer of Glimmer's shares, even if such a transfer resulted in a transfer of control of Glimmer. Kent was not a party to the joint venture agreement and it allowed the parties to enter into other transactions that could result in a transfer of control in Glimmer. Finally, the structure of the transaction was not designed to avoid the ROFR.

\section{COMMENTS}

While the terms of the joint venture agreement were critical in this case, the decision provides at least some guidance when dealing with rights of first refusal.

\section{BRINKERHOFF INTERNATIONAL INC. V. NUMAC ENERGY INC ${ }^{18}$ \\ 1. FACTS}

This case deals with the interpretation of several clauses of the 1993 Revised Standard Daywork Contract of the Canadian Association of Oil Well Drilling Contractors (the "Contract"). In particular, it deals with the interpretation of clause 12 relating to liability and indemnity.

Pursuant to the terms of the Contract, the plaintiff/respondent/contractor, Brinkerhoff International Inc. ("Brinkerhoff"), was to drill a well for the defendant/appellant/operator, Numac Energy Inc. ("Numac"). Brinkerhoff's drilling rig 
was to be used. During the course of the work, a wild well blowout occurred. Brinkerhoff's rig was destroyed and it sued Numac under the Contract for the loss of the rig and resulting economic loss.

The Contract provided that the contractor would be liable for any loss, damage or destruction of the contractor's surface equipment. It also provided that the operator would be liable for any damage to the contractor's "down-hole" equipment while it was below the surface. Finally, it provided that the operator would be liable, and indemnify the contractor, for the costs associated with a blowout or wild well.

In a preliminary application dealing with the interpretation of certain provisions of the Contract, the chambers judge held that the operator was responsible for the physical loss to the rig and, with respect to the claim for economic loss, that the Contract was ambiguous and that the determination of this claim should be made in the context of a trial of an issue. The operator appealed both findings while the contractor cross-appealed the second finding regarding economic loss.

\section{DECISION}

The Court of Appeal granted the appeal and the cross-appeal. The court held that the operator was not responsible for the physical damage to the rig in the event of a wild well blowout. The Court stated that the Contract was not ambiguous with respect to economic loss in wild well situations. It held that the operator was not responsible for such losses unless the loss could be shown to fall under the general provisions of subclause 12.10, which applied to situations not otherwise covered in the Contract.

The court noted that most of the subclauses of clause 12, dealing with liability and indemnity, addressed specific types of losses and situations. The general regime set out in subclauses 12.9 and 12.10, which refer to negligent or wilful acts or omissions, applied in situations not otherwise covered in the Contract. Therefore, in order to determine which party was responsible for a particular type of loss, it was necessary to first decide if that loss was covered by a specific provision.

The court held that the loss of the rig was covered by subclause 12.1 which concerns the contractor's liability "at all times for any loss, damage or destruction of Contractor's surface equipment...." On a plain reading of this language, the rig (which is used above the surface) is included in "surface equipment." The court rejected the contractor's argument that the term "rig" was not included in the term "equipment." Since there was no uniform use of the term "equipment" throughout the Contract, reference had to be made to the context of the provision in order to determine the exact meaning. The court also pointed out that subclause 12.1 contained three specific exceptions which, although they did not apply in this case, indicated that the parties had addressed their minds to situations in which the operator would be liable for the contractor's surface equipment, none of which involved wild wells. Therefore, the contractor was liable for the physical damage to its rig as a result of the wild well blowout. 
With respect to Brinkerhoff's claim for economic loss, the court concluded that the loss was not covered under the specific provisions of clause 12 . It held that the specific provisions in the Contract dealing with loss were directed at equipment loss and, without clear language requiring economic losses to also be covered, they were not. Without such language, it would not be reasonable to conclude that the economic losses flowing from the destruction of the rig were covered. Therefore, such economic loss had to be covered by the general provisions of the Contract (subclauses 12.9 and 12.10), which depended on questions of negligence (or wilful acts or omissions), which could not be determined in these proceedings.

\section{COMMENTS}

This case is useful in that it interprets the provisions of the Standard Daywork Contract of the Canadian Association of Oil Well Drilling Contractors, which is a widely used drilling contract in the oil and gas industry. With respect to economic losses, such losses may be covered under this standard form contract. If there is some negligence, wilful act or omission, the court leaves this question open.

\section{Gulf Canada Resources Ltd. v. Ulster Petroleums ltd. ${ }^{19}$ 1. FACTS}

This decision arises out of an appeal from an order of a Queen's Bench chambers judge upholding the decision of a master refusing an application by the defendants (appellants) to have some or all of the plaintiff's (respondent's) statement of claim struck out. The appeal also dealt with the chambers judge's determination of three preliminary issues. Gulf Canada Resources Ltd. ("Gulf') holds an overriding royalty with respect to production underlying certain lands. The lower formations reverted to the Crown and a Crown lease was issued to a party other than the party holding the shallow rights. The lease of the deep rights was reacquired by the Crown and the rights were offered to the holders of the shallow rights. Accordingly, at the relevant time, the ownership of all horizons were held by the same lessees.

The Energy Resources Conservation Board, as it then was, ("ERCB") designated the production as being from two zones, one of which was included in the formations surrendered and reacquired. The defendants were refusing to pay royalties on production allocated to that zone. However, in response to enquiries to the ERCB, Gulf was advised that

the Board's staff believes that these formations cannot be differentiated reliably from log data and interprets the Muskeg and Keg River as a continuous carbonate reserve in this well. The Board has historically designated wells producing from the Zama/Keg River zone as Keg River pools; consequently the Keg River 040 pool designation will not change.

By further letter dated October 3, 1994, the ERCB stated 
where the Zama member of the Muskeg formation and the Keg River formation form a continuous carbonate reservoir, or are in natural communication, the Board has historically called these pools Keg River pools for administrative purposes. Specifically, the Board has defined the pool producing from the 4-36 well as the Keg River 040 pool and recognizes that both formations are included in this pool. [Emphasis in original.]

The dispute between the parties was essentially twofold. First, was Gulf entitled to a royalty on all production from all zones and secondly, even if Gulf was only entitled to a royalty on the zones down to and including the base of the Muskeg formation, did that include the Keg River formation?

\section{MASTER'S DECISION}

The master declined to strike out any of the portions of the statement of claim and held that the court had jurisdiction to deal with the questions relating to the allocation of production among the zones and whether Gulf was entitled to royalties on such production.

\section{Chambers Judge}

The chambers judge accepted, and it was common ground between the parties, that the ERCB does not have jurisdiction to "make retroactive allocation of oil to a zone." Because of this lack of jurisdiction to make retroactive allocation, the chambers judge held that there had been no decision by the ERCB with respect to production occurring prior to the ERCB's designation of the pool. The chambers judge went on to find that the designation by the ERCB had not been done in a manner which would make the issue res judicata as far as Gulf was concerned because Gulf was not a party to the original decision and had maintained its opposing position since its letter written to the ERCB in 1992. He further found that the terminology of the ERCB's letter was such that it indicated that the ERCB was making the determination "for administrative purposes only."

With respect to the preliminary issues, the chambers judge found that the ERCB had not, as against Gulf, deemed production from the 4-36 well to be solely from the Keg River formation. He also found that the court had jurisdiction to make prospective determinations of the source of production with respect to that well. The chambers judge characterized the dispute as a contractual dispute over a matter arising under the Oil and Gas Conservation $\mathrm{Act}^{2 \mathrm{O}}$ and arguably not itself a matter arising under that Act. He concluded that "if the Court were to refuse jurisdiction in this matter, the plaintiff (Gulf) would be denied a forum in which to seek a remedy...."

\section{COURT OF APPEAL}

The Court of Appeal characterized this claim as an action for breach of contract and breach of fiduciary duty between a gross overriding royalty holder and an owner of the 
leasehold interest in the property. It found that Gulf had the right to seek enforcement of its right in court and further that if Gulf was correct that it was entitled to gross overriding royalty on all hydrocarbons produced from the surface to basement lands, the question of allocation would be moot. It went on to find that if Gulf's alternate position prevailed, the issue of the source of production would become relevant and that both items were triable issues.

The court, in characterizing the matter as a contractual dispute, determined that the effect of an ERCB determination as to zone on the parties would depend upon the interpretation of the contract. They held that it would be possible for the parties to agree to be bound by such designation or that the allocation would be otherwise determined. Accordingly, the question was not one of jurisdiction but rather one of interpretation of the contract.

Furthermore, the court indicated that if it were found that the appellants owed a fiduciary duty not to produce from the Keg River formation where the effect would be to drain from the Muskeg formation, the respondent would be entitled to damages. It was held that there was nothing in the statutory scheme to suggest that the court's jurisdiction to grant an appropriate remedy in such a situation was in any way limited.

The court distinguished the situation from a dispute among holders of leases to different zones and noted that the legislation was designed to deal with disputes between such parties and not disputes by royalty owners.

The Court of Appeal reiterated that it will pay the highest degree of deference to boards with expertise, such as that possessed by the ERCB, and defer to its decisions and to its jurisdiction where possible. However, in this case, neither the Oil and Gas Conservation Act nor the Energy Resources Conservation $A c{ }^{21}$ provides for remedies for contractual breach of a royalty agreement nor does it provide the means for retroactive orders. It went on to hold that if the court found that Gulf was entitled to a remedy that required the calculation of retroactive allocation of the source of production of oil, then the court had the right and the jurisdiction to make that finding.

The court declined to make any interpretation of the designation orders on the preliminary basis without having the full contracts and commercial context evidence before them.

In summary, the appeal was dismissed and the Court of Appeal declined to decide whether the ERCB had made a binding determination as to the allocation of production from the Keg River formation. It found that the second issue relating to jurisdiction was not so much a question of jurisdiction as a question of the interpretation of the contract giving rise to the overriding royalty. 


\section{COMMENTS}

This case specifically addresses the inter-relationship between the jurisdictions of administrative boards and the Courts.

\section{E. RAPATAX (1987) INC. v. CANTAX CORP.22}

1. FACTS

This case arises out of a commercial agreement to develop software for an income tax application. The agreement was for an indefinite term, as it did not specify a termination date or contain any mechanism for termination. At trial, the plaintiff was successful and was awarded damages for breach of contract on the basis that the defendant had unilaterally terminated the contract shortly after the arrangement had been entered into and prior to any products being developed for the market. The trial judge accepted the plaintiff's expert's assessment of the damages, with the exception of the discount rate to be applied and a limiting factor for contingencies, which he adopted from the evidence of the defendant's expert.

On appeal, the defendant accepted that there was a binding contract which had been breached but argued that the trial judge had erred in not determining whether the contract was terminable upon reasonable notice and failing to determine what constituted reasonable notice. The defendant also appealed the quantification of damages.

\section{DECISION}

- The Court of Appeal held that commercial contracts for an indefinite term are presumed to be perpetual but that that is a rebuttable presumption. Accordingly, it is necessary for a court to look at the relationship between the parties and the nature and terms of the contract to determine whether there is a basis upon which to conclude that the contract is terminable upon reasonable notice.

In this particular case, the Court of Appeal held that it was inconceivable that either party would have wished to forever be bound by the contract. The court distinguished this circumstance from that discussed in Fort Francis (Town) v. Boise Cascade Canada $L t d .{ }^{23}$ where there was a complex legislative scheme and the parties were irreversibly committed to the project such that restoration to their precontractual position was impossible.

The court determined that, as the matter was not addressed at trial and it was impossible to do so on the record before the Court of Appeal, the matter would be returned for trial on the two issues of what reasonable notice would be in these circumstances and a determination of damages based upon that notice. 


\section{COMMENTS}

The case highlights the importance for parties entering into business relations to contemplate and address those circumstances in which the relationship may be terminated.

\section{Creditor' Rights}

\section{A. BANK OF MONTREAL V. DYNEX PETROLEUM LTD. ${ }^{24}$ \\ 1. FACTS}

The facts are adequately set out in the headnote as follows:

The defendant [Dynex] Ltd. and its predecessor companies granted overriding royalty and net profit interests to other defendants [the "ORR owners"] regarding [Dynex's] oil and gas leases. Later, [Dynex] gave a debenture to the plaintiff bank, employing the leases as security. All of the documentation supporting the debenture stated that the ORR interests were permitted encumbrances. [Dynex] later defaulted on the bank loan. Shortly thereafter, [Dynex] was petitioned into bankruptcy. The bank brought an action against the bankrupt and the [ORR owners], seeking a declaration that the bank's claim ranked in priority to those of the [ORR owners] in the context of the bankruptcy. All the parties requested a determination of the priorities between the bank and the [ORR owners] after the bankruptcy.

\section{DECISION}

The court held that the ORR owners' interests had priority over the bank's debenture. The court stated that the priorities between the bank and the ORR owners related less to the status of these parties as a secured creditor and unsecured creditors, respectively, than to the effect of the bankruptcy on the subordination. The subordination of the bank's interest to the ORR owners' interests survived Dynex's bankruptcy. The ORR owners were entitled to recover from the bank their losses that were not otherwise recovered from the trustee.

In an earlier related decision, ${ }^{25}$ the court found that the ORR owners' rights to royalties and net profit interests were choses in action and that the ORR owners had a right to receive a portion of the proceeds of the sale of petroleum and natural gas substances from the leases held by Dynex. The royalty and net profit interests were not rights to the sale of a specific tangible asset. The agreements did not create an interest in a lease, and thus a real property interest. They were interests created downstream of the lease. Therefore, the ORR owners could not be secured creditors by virtue of any real property interest. Ordinarily, choses in action would constitute simple debts allowing the claimant to register an unsecured claim with the trustee in bankruptcy.

25 Bank of Montreal v. Dynex Petroleum Lid. (1995), 39 Alta. L.R. (3d) 66 (Q.B.). 
In this decision, the court discussed various potential classifications of the ORR owners and their interests:

(1) trust interests (trust property not forming part of bankrupt's estate);

(2) secured creditors as to real property by virtue of real property interests;

(3) secured creditors as to personal property by virtue of personal property interests; and

unsecured creditors.

The court held that there was nothing in the documentation that showed any intention to create a trust. With respect to (1), the court simply referred to its earlier decision which held that these interests were not real property interests. With respect to (3), the court noted that while the ORR interests (choses in action) were registerable under the Personal Property Security Act, ${ }^{26}$ none were registered in this case. The court ultimately decided that the ORR owners were simply unsecured creditors.

As purely unsecured creditors, the interests of the ORR owners ranked below that of the bank. However, the subordination agreement which the bank gave in favour of the ORR owners survived the bankruptcy of Dynex. Therefore, as between the bank and the ORR owners, the bank's subordination was a subordination of its interests to those of the ORR owners. The court stated that the bankruptcy did not extinguish the choses in action of the ORR owners, but rather changed the nature of the enforcement available to them. The subordination agreement was broad, unambiguous and clear and did not contemplate a bankruptcy terminating its existence.

The trustee had the right to sell the real and personal property of Dynex on bankruptcy. As against the trustee, the ORR owners were unsecured creditors and the trustee could sell the assets unencumbered by their interests. However, as between the bank and the ORR owners, the bank had to account to the third parties for any funds received directly or through the trustee from the sale of the ORR owners' interests.

\section{COMMENTS}

The court reaffirmed its earlier decision between the same parties that overriding royalty and net profit interests in an oil and gas lease were choses in action and were not interests in real property. The court in this case held that this subordination agreement was clearly and broadly worded and survived the bankruptcy. The terms of a subordination agreement (and thus its scope), are up to the parties negotiating and entering into the agreement. 
The authors understand that both the earlier decision and this decision are being appealed to the Court of Appeal. However, at the time of writing neither appeal has been heard.

\section{DIRECTORS' LIABILITY}

\section{A. NORMART MANAGEMENT LTD. V. WEST HILL REDEVELOPMENT CO. ${ }^{27}$}

\section{FACTS}

The two corporate respondents entered into a joint venture agreement with the appellant corporation which provided that they each owed each other a "duty of utmost good faith" with respect to their relationship with one another under the agreement. The appellant corporation brought an action, making a number of claims against the two respondent corporations as well as their officers and directors. With respect to the allegations against the individuals, the appellant alleged they had conspired with and among each other directly and through the respondent corporations to control and injure the appellant corporation. The individuals were successful in a motion to dismiss the claims against them. The appellants appealed.

\section{DECISION}

The Court of Appeal dealt with two issues: first, whether the appellant pleaded a sustainable cause of action in conspiracy and, second, if there was a sustainable conspiracy action, did it merge with the action for breach of contract?

The court held that on a plain reading of the statement of claim, the appellant was attempting to convert its action for breach of contract and breach of fiduciary duty arising out of that contract into a personal action against the officers and directors of the respondent corporations. The court stated:

It is well established that the directing minds of corporations cannot be held civilly liable for the actions of the corporations they control and direct unless there is some conduct on the part of those directing minds that it is either tortious in itself or exhibits a separate identity or interest from that of the corporations such as to make the acts or conduct complained of those of the directing minds. ${ }^{28}$

The court held that the statement of claim could not support any allegations that the personal defendants were at any time acting outside of their capacities as directors and officers of the corporations they directed. All of the impugned transactions were completed in the name of the corporate defendants and for the benefit of the corporate defendants. The court held that the directing mind of a corporation cannot, by causing the corporation to act in a certain way, be said to have made an agreement with that corporation. Further, while a directing mind could make an agreement with another corporation by making an agreement with a directing mind of that other corporation, 
if both directing minds were acting on behalf of their respective corporations, then the agreement was between the two corporations.

Since the court found that there was no sustainable cause of action in conspiracy against the individual defendants, there was no issue as to merger of the conspiracy action and the action for breach of contract.

\section{COMMENTS}

This case is good recent authority for the proposition that officers and directors of a corporation are not personally liable for the acts of the corporation in most instances.

\section{ENVIRONMENT}

\section{A. LABRADOR INUIT ASSN. V. NEWFOUNDLAND (MINISTER OF ENVIRONMENT AND LABOUR) ${ }^{29}$}

\section{FACTS}

This case arises out of the environmental assessment processes involved in the mining development proposed at Voisey's Bay in northern Labrador. In order to avoid duplication of federal and provincial environmental assessments, a memorandum of understanding dated January 30, 1997 was signed among the governments of Canada, Newfoundland and Labrador, the Labrador Inuit Association and the Innu Nation. The question which arose was whether the construction of temporary access roads and a temporary airstrip would fall under the memorandum of understanding as a result of the Minister of the Environment for Newfoundland having granted approval for the construction of those works.

\section{DECISION}

Although the trial judge dismissed the application of the aboriginal peoples' organizations to quash the minister's decision and for a declaration that the temporary projects were part of the undertaking covered by the memorandum of understanding, the Court of Appeal overturned that decision and declared that the temporary works were part of the overall project covered by the memorandum of understanding.

\section{COMMENTS}

This decision exemplifies the role of courts in reviewing government approvals to ensure that environmental regulations are not circumvented. 


\section{Fiduciary Duties}

\section{A. Gulf Canada Resources ltd. v. Ulster Petroleums ltd. ${ }^{30}$}

See the discussion set out at IV.D.

\section{B. MOCO Resources LTD. v. UNOCAL CANADA RESOURCES ${ }^{31}$}

\section{FACTS}

The plaintiffs had small working interests in sections 1 and 12 which bordered the Kakwa unit. There was a well completed but shut in on the south half of section 12 and operations in respect of those lands was governed by the 1974 CAPL operating procedure. However, the south half of section 12 was not pooled with the balance of the section to form a spacing unit. Unocal acquired the majority interest in the whole of section 12 and became the operator of the well. Unocal was also the largest interest owner and the operator of the Kakwa unit. The plaintiffs alleged that Unocal, as operator of the shut-in well, failed to carry out its duties to the working interest owners because it failed to do what was necessary and appropriate for the well to produce and the owners to realize value from their assets.

Although various options were considered, including tying in the well, enlarging the unit to encompass one or both of the adjacent sections, and selling the adjacent sections to the working interest owners of the unit, nothing was achieved for over two years. At that time, Unocal resigned as operator of the non-unitized well.

\section{DECISION}

Kent $\mathbf{J}$. found that Unocal did owe fiduciary obligations to the working interest owners of the non-unitized well and that it had breached those obligations. These findings were based, in part, on Unocal holding itself out as acting for the working interest owners.

In approaching the question of whether Unocal owed a fiduciary duty, the judge noted that this is not a situation where the relationship is "innately fiduciary." In particular, she commented that the relationship among working interest owners and between those owners and their operator is fundamentally commercial. She went on to say that the operator may have fiduciary duties and adopted the analysis of Hunt J. (as she then was) in Erehwon Exploration v. Northstar Energy Corporation, ${ }^{32}$ where she considered the components of a fiduciary relationship in the context of an operator under a CAPL agreement. In that decision, Hunt J. started with the characteristics set out by the Supreme Court of Canada in Frame v. Smith, ${ }^{33}$ as follows: the fiduciary has 
the scope for the exercise of power or discretion; the fiduciary can exercise that power or discretion unilaterally so as to effect the beneficiary's practical or legal interests; and the beneficiary is peculiarly vulnerable to or at the mercy of the fiduciary. Kent $J$. then went on to comment that not all functions of an operator under CAPL are those of a fiduciary and that there must be evidence that the alleged fiduciary has agreed to relinquish its self interests and act solely on behalf of the beneficiary.

Kent J. went on to find that Unocal was in a conflict of interest position in that the interests of Unocal itself, the interests of the unit working interest owners and the interests of the working interest owners in the non-unitized well were irreconcilable. She found that the failure to recognize the conflict and inform the working interest owners in the non-unitized well of Unocal's real priorities was the breach and that as a result of that breach, the production from the lands was delayed. She went on to find, however, that once Unocal resigned as operator of the non-unitized well, that its fiduciary obligation to the other working interest owners in the non-unitized well were at an end.

Having found that the production was delayed by some eleven months, the court requested further argument from counsel (the results of which are not reported in the decision) as to whether the court has jurisdiction to either refer the matter to the Alberta Energy and Utilities Board for its consideration, or make a declaration that the plaintiffs are entitled to compensation equivalent to the eleven months' delay incurred as a result of the defendant's breach of its fiduciary duty leaving quantification of that amount once production begins either by board order or negotiation. She also sought argument as to whether it is appropriate to make either of those orders in this case.

\section{COMMENTS}

In the authors' view, this case represents a further example of decisions confirming that not all duties owed by operators to their working interest owners are fiduciary duties but that an analysis must be pursued to determine whether any particular obligation does give rise to a fiduciary duty. Both in this case and in the Erehwon ${ }^{34}$ case, the court took account of the fact that the working interest owners were small companies which did not have an equality of bargaining power with the operator. While that is only one of the factors looked at, it bears consideration where operators are making decisions as to how to develop properties.

\section{LANDS, LEASES AND TITLES}

A. ACANTHUS RESOURCES LTD. v. CUNNINGHAM ${ }^{35}$

See the discussion set out at XIII.A. 


\section{B. HiLL v. NOVA SCOTIA (ATTORNEY GENERAL)}

\section{FACTS}

In order to build a controlled-access highway, the Province of Nova Scotia expropriated land which bisected the Hill farm. The Department of Transport represented that, as part of the compensation, Hill would receive an interest in the highway lands, which would permit him to move people, equipment and cattle back and forth across the highway. In compliance with these representations, the Department of Transport constructed fences, gates and ramps and maintained them for over twentyseven years. The Hills used them during this time. The Department of Transportation then undertook a twinning of the highway in the area of the original expropriation and subsequently removed the access ramps without providing alternate access to the sons of Hill who were now operating the farm. The Crown denied the grant of an interest in the land because the representation contravened s. 21 of the Nova Scotia Public Highways $A c t,{ }^{37}$ which provided that no person should construct a private road, entrance way or gate connecting with or opening on a controlled access highway without a written permit from the minister. The trial judge held that the Hill sons were entitled to an equitable easement across the highway. The Court of Appeal overturned that decision and the Hill sons appealed. The issue to be resolved was whether, as part of the consideration for the expropriated lands, the province granted an equitable interest in those lands permitting the movement of cattle and equipment across the highway.

\section{DECISION}

The Supreme Court of Canada upheld the Hills' interest in the land and found that the Hills had acquired an "equitable permission" (or interest) to enter upon and cross the highway. The conduct of the Crown in maintaining the structures for twenty-seven years served to confirm and entrench the representation that the Hills were to have an interest in land. The interest in land formed part of the compensation the Hills were to receive for the expropriation of their property. Notwithstanding the unsatisfied requirement in paragraph 21(1)(a) of the Public Highways Act that this permission should be in writing, paragraph 21 was merely a reflection of the Statute of Frauds ${ }^{38}$ which is designed to prevent fraud. Where the terms of an agreement have already been carried out, the danger of fraud is reduced or averted. To require writing pursuant to s. 21 in this instance would not serve the purpose of averting a fraud. Rather, the Hills would be defrauded. In any event, the doctrine of part performance prevented the Crown from relying on the writing requirement. A writing requirement cannot circumvent the application of the doctrine of part performance. Estoppel was not applicable either. The writing requirement must give way in the face of part performance or estoppel by conduct because the part performance or conduct fulfils the very purpose of a written document. 
The landowner acquired an equitable permission in the form of a right of way over the highway. An equitable permission is a compensable interest in land within the broad meaning of that term found in paragraph $1(\mathrm{c})$ of the Nova Scotia Expropriation Act. ${ }^{39}$

\section{COMMENTS}

The Supreme Court of Canada held that the part performance of an oral contract is paramount over a writing requirement, either under the Statute of Frauds or some other statute whose writing requirement is designed to prevent fraud. However, the court indicated that other statutory writing requirements may be designed for other purposes and, therefore, their writing requirements will generally be mandatory.

\section{CANADIAN CRUDE SEPARATORS INC. v. MYCHALUK ${ }^{40}$}

\section{FACTS}

Alexander Mychaluk granted a surface lease to Gulf (the "Lease"); Gulf registered a Caveat against the title to the lands; and Alexander Mychaluk sold his interest in the lands to his sons, the appellants, and reserved to himself the compensation or monies payable pursuant to the lease. Alexander Mychaluk filed a caveat in respect of that reservation. Upon Alexander Mychaluk's death, his wife inherited the right to receive compensation payable pursuant to the lease. The appellants sold their interests in the surface title to Jameson and Turville and reserved out their mother's right to receive compensation under the lease and the right to grant renewals or extensions of the lease. The appellants filed a caveat claiming an interest in the title to the lands under the Jameson and Turville agreement and appended a copy of the agreement to their caveat. Upon their mother's death, the appellants inherited their mother's right to receive the compensation. Jameson and Turville sold the lands to the County of Stettler No. 6 and the county was notified of the interest claimed by the appellants by letter from the county's solicitors. Canadian Crude Separators, Inc. ("CCSI") then acquired the lessee's interest under the lease. Later CCSI acquired the county's interest in the title to the lands. The three caveats in respect of the initial Gulf lease (now in the name of CCSI), the reservation by Alexander Mychaluk and the reservation by the appellants all remained on title after the sale to CCSI and remained registered against the title at the time of the hearing. Following registration of the title to the lands in its name, CCSI made payments to the appellants under the lease. Following a compensation review by the Surface Rights Board, CCSI made a further payment to the appellants to reflect the increased compensation ordered by the Surface Rights Board. Subsequently, CCSI offered to purchase the appellants' interest in the lands, prior to giving any indication to the appellants that CCSI had any intention of challenging the appellants' entitlement to receive compensation or taking the position that the appellants had no further interest in the lands. CCSI continues to carry out operations on the lands and no reclamation certificate has been issued. 


\section{DECISION}

McBain J. held that the assignments, or reservations, by Alexander Mychaluk on the sale to his sons and by the sons on their sale to Jameson and Turville did not create interests in land which would support a caveat as of the date of those transactions. $\mathrm{He}$ rejected the argument that the amendments to the Law of Property $A c t^{A 1}$ in 1985 characterizing assignments of rent as interests in land would validate the previously filed caveats even though CCSI did not acquire its interest in the lands until after those amendments. He further found that the lease had terminated by operation of the doctrine of merger once CCSI acquired both the lessee's interest and the surface interest notwithstanding the reservations. He declined to find that CCSI and the sons had been novated into the lease. Lastly, he found that ss. 129(1) of the Alberta Environmental Protection and Enhancement $A c t^{A 2}$ did not continue the obligation to make the rental payment because the Lease had not been "surrendered" as defined in that Act.

The Mychaluks applied for leave to appeal the decision and in a decision dated February 24, 1998, Hunt J. refused leave. All parties acknowledged that the appropriate test to be applied on the application for leave to appeal was that set out by O'Leary, J.A. in Ferguson v. Ranger Oil Ltd. ${ }^{43}$ that leave should be granted if one or more of the grounds of appeal raised has a reasonable prospect of success and that success would have a significant impact on the parties; and that leave should also be granted where the appeal raises a question of law or procedure of importance to the operation of the Act.

In coming to her determination, Hunt $J$. found that the question of whether the interests reserved created an interest in land was a matter of determining the intention of the parties at the time the interest was created. She acknowledged the distinction between a reservation created by a seller and a mere assignment of rents but finds that, based upon the language of the agreement for sale from Alexander Mychaluk to his sons, that it would not suffice to demonstrate an intention to create an interest in land. In particular, she notes that that document refers to "compensation" and "monies payable." She goes on to find that the interest reserved by the sons on their sale to Jameson and Turville cannot be greater than the interest reserved by Alexander as it arises out of that interest. Accordingly, notwithstanding the stronger language in the agreement with Jameson and Turville, the interest was not transformed into an interest in land at that point.

The Mychaluks argued that the operation of s. 59.1 of the Law of Property Act, which provides that assignments of rents are interests in land and which came into effect in 1985 before CCSI acquired its interest in the land, should operate to validate the earlier caveats. Hunt J. rejected this argument and commented that, notwithstanding her comments in the Scurry-Rainbow Oil Ltd. v. Galloway Estate ${ }^{44}$ to the effect that 
Northland Bank v. Van de Geer's did not preclude the argument that the section might be applied retroactively. In this case, there was no reasonable prospect of success on that argument, as Alexander Mychaluk did not intend to create an interest in land when he reserved the rentals to himself.

The Mychaluks argued that CCSI had not acquired the entire freehold surface interest, as there had been a reservation out of the transfer to Jameson and Turville of some of the rights of the freehold owner. Hunt $J$. found that this argument depended upon whether or not Mychaluk had reserved an interest in land. Since he had not, whatever interest was held did not bar the operation of the doctrine of merger. She also found that the cases of Sherman v. Ogonoski $i^{46}$ and Fleck v. Davidson Estate, ${ }^{47}$ where the purchasers were found to be bound by the reservation of rentals, did not apply because there were no direct contractual relationships between the Mychaluks and CCSI.

She found that McBain J.'s decision that a novation had not occurred was far from unreasonable and, accordingly, declined leave on that point.

Lastly, with respect to s. 129.1 of the Environmental Protection and Enhancement $A c t$, Hunt $\mathrm{J}$. found that there was not a "surrender" in these circumstances and, very importantly for other parties who have reserved surface rentals to themselves on the sale of their surface lands, that the Mychaluks did not fit the definition of "owner" under the Act.

\section{COMMENTS}

There are a number of issues in this decision which will have broad application. In particular, one must note the narrow interpretation placed upon the obligation to pay rentals after the surrender of a surface lease and the parties to whom those rentals must be paid. Similarly, the implications for persons who reserved surface rentals on a sale of their lands prior to 1985 should be reviewed and consideration given as to whether the registration of new caveats is required.

\section{MCDONELL ESTATE V. SCOTT WORLD WIDE INC ${ }^{48}$ \\ 1. FACTS}

In 1900, McDonell and others granted the fee simple estate in certain lands to a mining company. The deed contained a reservation of timber rights which provided as follows: 
Reserving to the said Edward C. McDonell the right to cut and carry away the standing timber on the lands herein described, and the said [mining company] and its successors to have the right to cut and use any timber on said lands that it may deem necessary for mining and milling purposes. ${ }^{49}$

McDonell's estate commenced an action for a declaration as to the estate's title with respect to the timber, an accounting and damages. The estate's position was that the words of the reservation were an "exception," excepting out of the conveyance a fee simple estate in the trees on the subject lands. As a result, title passed to McDonell's estate when he died in 1908. Scott World Wide Inc. ("Scott World"), successor to the fee simple estate, argued that the right created by the reservation was, at best, a life interest only which came to an end on McDonell's death.

The chambers judge held that the reservation was an "exception," excepting out of the conveyance of fee simple interest in the trees. Further, he held that the fee simple interest was with respect to trees which were alive on the date of the conveyance and capable of becoming timber at some future time, or those which had become timber. Scott World appealed.

\section{DECISION}

The Court of Appeal agreed with the appellant's position. The court held that the words of the reservation were clear and unambiguous and that a fee simple interest in the timber was not excepted out of the conveyance. He noted that the word "exception" was not used and that the clear right stated in the reservation was "the right to cut and carry away the standing timber." The words of the reservation imported nothing more than a right in the nature of a profit a prendre to enter upon the land and to cut down trees and take them away.

The court did note, however, that the authorities establish that an estate of inheritance can be granted in a tree, with an interest in the soil sufficient for its growth, while the fee in the soil remains with the grantor. However, the reservation in this case did not except out a fee simple interest in the trees.

The court referred to the distinction between an "exception" and a "reservation." The former operates to take something out of the thing granted which would otherwise pass or be included. With the latter, the grantor creates and reserves to himself some right, interest, or profit in the estate granted, which had no previous existence as such.

The court held that the extent of McDonell's right acquired by a virtue of the reservation was in the nature of a profit $\dot{a}$ prendre to enter upon the lands and to cut down trees and take them away. It held that such right ended, at the latest time, at McDonell's death in 1908. 


\section{COMMENTS}

This case is interesting in that it focuses on the distinction between a reservation and an exception contained in a deed.

\section{Leave to Appeal to the Supreme Court of Canada}

\section{A. Luscar Ltd. v. PEMbina Resources LtD. ${ }^{50}$}

An application for leave to appeal to the Supreme Court of Canada was dismissed without reasons on August 17, 1995.

B. UNITED STATES V. IVEY $\mathrm{Y}^{\mathrm{S}}$

An application for leave to appeal to the Supreme Court of Canada was dismissed without reasons on May 29, 1997..33

\section{ALBERTA WILDERNESS ASSOCIATION V. EXPRESS PIPELINES LTD. ${ }^{54}$}

An application for leave to appeal to the Supreme Court of Canada was filed on October 30, 1996. ${ }^{\text {ss }}$

D. ROBERT LEMMONS \& ASSOCIATES V. GANNON BROS. ENERGY LTD. ${ }^{36}$

An application for leave to appeal to the Supreme Court of Canada was dismissed without reasons on June $26,1997 .{ }^{57}$

\section{Limitations of ACtions}

\section{A. NORTHLAND BANK V. WILLSON \\ 1. FACTS}

Two sets of defendants, who were former officers and directors of the collapsed Northland Bank (the "Bank"), in two related actions commenced third party proceedings against the auditors and other financial advisors of the Bank. The third parties in one action were granted summary judgment dismissing the third party claims

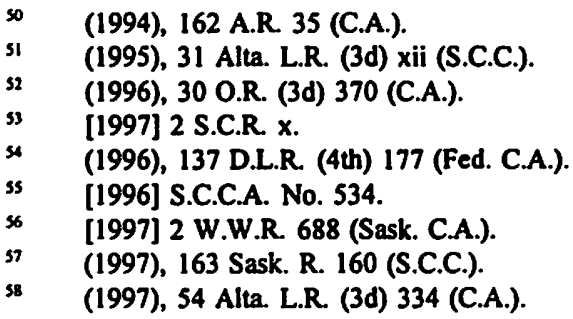


for contribution against them brought under the Alberta Tort-Feasors Act. ${ }^{59}$ The Queen's Bench judge held that the limitation period applicable to the defendants' claim for contribution against the third parties was that which was applicable to the plaintiffs. The defendants appealed.

\title{
2. DECISION
}

The appeals were allowed in part in one action and dismissed in the other. The court held that the principal of res judicata applied to the second action even though different parties were involved. The same limitation applied to all defendants insofar as their claims were for contribution only under the Act. However, the court held that the claims specifically against the third party auditors were arguably separate causes of action based on independent duties owed by the auditors and a different limitation period might apply to this claim. This issue could not be disposed of on a summary judgment application, since there were triable issues.

\section{COMMENTS}

This case stands for the proposition that the limitation period that applies against a plaintiff applies against a defendant in a third party action for contribution only under the Tort-Feasors $A c t^{60}$ (i.e. no claim for indemnification based on separate duties). However, in situations involving separate causes of action by a defendant against a third party, a different limitation period may apply.

\section{B. 602533 ONTARo INC v. SHell CANADA LTD. ${ }^{61}$ \\ 1. FACTS}

In 1990, 602533 Ontario Inc. ("602533") brought an action against Shell Canada Ltd. ("Shell") relating to allegedly defective underground gasoline tanks for breach of contract, deceit, misrepresentation, breach of warranty and negligent failure to warn. At the time the action was commenced, 602533 was a non-existent entity due to its dissolution for "defaulting complying with the Corporations Tax Act"62 [sic] of Ontario. No steps were taken to remedy the default and revive the corporation until 1996. 602533 declined a settlement offer and the action lay dormant until the sons of the sole shareholder filed an amended claim in 1995. Shell then discovered that 602533 had been dissolved. It defended by claiming that 602533 had no status to commence or continue the action. 602533 was revived under ss. 241(5) of the Ontario Business Corporations $A C t^{3}$ in 1996. Shell brought a motion for summary judgment claiming that the limitation period had expired prior to 602533 being revived. The motions judge granted summary judgment on the original claim and dismissed as statute-barred the

\author{
R.S.A. 1980, c. T-6. \\ Ibid. \\ (1998), 155 D.L.R. (4th) 562 (Ont. C.A.). \\ R.S.O. 1990 , c. 40. \\ R.S.O. 1990 , c. B-16.
}


amended claims grounded in tort and contract. 602533 appealed to the Ontario Court of Appeal.

\section{DECISION}

The Ontario Court of Appeal held that the 1990 claim was a nullity since 602533 was dissolved at the time the action was commenced. Subection 241(5) of the Act expressly made revival of the company subject to any rights acquired by any person after its dissolution. The court held that the expiry of the limitation period was a post-dissolution right upon which Shell could rely to defeat the claim. A defendant need not show actual or any prejudice to take advantage of a limitation defence. Also, equitable relief was not warranted since the sole shareholder and his sons who were active in the business could have taken timely steps to revive the corporation before the expiration of the limitation period. Finally, the court held that waiver and estoppel could not help 602533 since Shell was not aware of the dissolution prior to 1996.

\section{COMMENTS}

The court finds that the expiry of a statutory limitation period between the issuance of a claim by a dissolved corporation and its subsequent revival creates a postdissolution right in a defendant. The court disagrees with McDonald J. in Modern Livestock Ltd. v. Kansa General Insurance Co. ${ }^{64}$ The court prefers the position enunciated by Eberle J. in Profit Sharing Investors of Canada Ltd. v. Coffee Vending Services (Ottawa) Ltd. ${ }^{65}$ The court also confirms that waiver and estoppel do not apply when a party is not aware of the relevant facts to which waiver and estoppel could apply.

\section{Practice}

\section{A. SPECIALTY STEELS V. SUNCOR INC. ${ }^{66}$ \\ 1. FACTS}

Suncor Inc.'s ("Suncor") plant was destroyed by fire. Suncor's manager was instructed by a member of Suncor's legal staff to investigate and report on the cause of the fire. Suncor purchased replacement fittings and flanges from Specialty Steels ("Specialty"). Suncor discovered that a number of the fittings had hardness ratings in excess of those specified. The manager, who was in the course of preparing his fire report, was then told to investigate and report on the extent and cause of the hardness problem. The manager was instructed to prepare only one copy of the report and deliver it only to Suncor's director of legal services. At that time, no litigation was in progress, threatened or contemplated. 
Before the report was completed, Specialty commenced proceedings against Suncor to recover the price of the fittings. Suncor's manager completed and delivered his report shortly thereafter. Suncor filed a defence and counterclaim against Specialty and others claiming damages related to the faulty fittings. Specialty's application to compel Suncor to disclose the report was dismissed on the basis that the report was privileged. The lower court applied the "dominant purpose" test. Specialty appealed.

\section{DECISION}

The appeal was dismissed (with Conrad J.A. dissenting). The majority of the court held that whether a document falls within litigation privilege is determined by assessing the dominant purpose of the document when it is physically created. In the present case, although the dominant purpose for requesting the report was not to use it in litigation, litigation had begun when the report was created as a document and delivered. The concept of dominant purpose assumes that creation of a document may be motivated by more than one intention. A servient purpose may mature into a dominant purpose, which is what happened here, and vice versa. The dominant purpose at the critical time here was litigation.

\section{COMMENTS}

The time of a document's creation is the critical time for assessing its dominant purpose. Facts stated in a privileged document, and other documents referred to in it, may or may not be privileged. Unless such facts and documents are otherwise privileged, referring to them in a privileged document does not protect them from disclosure and they may be obtained by other means of discovery.

\section{B. ANDERSON EXPLORATION LTD. V. PAN-ALBERTA GAS LTD. ${ }^{67}$ \\ 1. FACTS}

The defendant entered into contracts with 425 natural gas producers to provide natural gas for a common pool. The defendant markets the pool in accordance with contractual and statutory guidelines and distributes to each producer its proportionate share of the profits. The plaintiffs were nine of the 425 producers, who brought an action against the defendant for breach of fiduciary duty. The defendant applied for an order that the decision in this action bind the remaining 416 producers. The application was brought on the grounds that all of the producers had a common interest in the outcome of the litigation and if they were bound by the decision in this action there was no need for each producer to commence separate actions on the same issues.

\section{DECISION}

The court held that rule $\mathbf{4 2}$ of the Alberta Rules of Court, dealing with representative actions, is ambiguous as to the procedural aspects of commencing a representative 
action. The rule neither expressly authorizes nor expressly prohibits a defendant from applying to have a plaintiff sue on behalf of a representative class. The Rule should not be given a limited interpretation that would prevent a defendant from taking a step that may avoid a multiplicity of actions.

The factors to be considered when determining whether an action is appropriate for a representative action are:

(1) the class must be capable of clear and definite definition;

(2) the principal issues of fact and law must be the same;

(3) success for one of the plaintiffs will mean success for all; and

(4) no individual assessment of the claims of individual plaintiffs need be made.

These factors were met in this case. The class was clearly capable of definition. The court excluded from the class any producers that were involved in specific transactions giving rise to the allegations of the defendant's breach of fiduciary duty. The significant issues of fact and law were the same for all producers. The parties were subject to the same legislative regime and similar fundamental contractual terms. The defendant agreed that if a fiduciary duty was found owing to these plaintiffs, it would concede that all producers were owed the same fiduciary duty. Success for the plaintiffs would mean success for all of the producers in the class. Finally, there need not be individual assessments of damages. If the plaintiffs proved that the defendant engaged in transactions that violated its fiduciary duties, a common fund could be established. Individual damages were easily calculable based on each producers' proportionate share of the revenue, which could be found in the individual contracts.

\section{COMMENTS}

The court's finding that a defendant may apply to convert an action into a representative action, despite the plaintiffs' unwillingness to convert the action into a class action, may seem harsh on the plaintiffs. However, on balance the decision is warranted since, otherwise, the defendant could face hundreds more actions against it, essentially dealing with the same issue. The court also noted that the original nine plaintiffs would not suffer any great injustice and the representative action would not result in any additional costs that had not already been anticipated. In any event, such issues could be dealt with as they arise.

\section{Royalties}

\section{A. ACANTHUS RESOURCES LTD. v. CUNNINGHAM ${ }^{68}$}

\section{FACTS}

This case arises out of a contest over freehold oil and gas leases and incorporates two claims, the first by the plaintiffs for overpayment of royalties arising out of a 
failure to deduct the cost of treating oil to remove water, and the second by the lessors claiming that the leases were invalid.

Acanthus Resources Ltd. ("Acanthus") was the successor in interest under leases originally issued to Trapper Resources Ltd. ("Trapper"). Neither Trapper nor any of the succeeding lessees prior to Acanthus had made deductions for removal of water at the central battery facility, although deductions had been made for transporting the oil from that facility to the pipeline.

The lease contained the following language: "the lessee shall remit to the lessor on or before the 25th day of each month, (a) an amount equal to the current market value at the wellhead on the date of delivery of $17 \%$ of the crude oil and crude naptha produced, saved and marketed from the said lands during the preceding month...."

When Acanthus began deducting the amounts for treatment from the royalty payments, it was served with a "Notice to Take Proceedings on Caveat." It then repaid the amounts it had deducted but reserved its right to seek a judicial determination of that issue.

\section{DECISION}

Hart J. held that the point of sale for the substances was not at the wellhead but rather downstream of the wellhead at an inlet terminal of a nearby pipeline. Accordingly, he held that the costs downstream of the wellhead are essentially the treating costs incurred to remove water from the crude oil, the costs of storing the treated oil in the battery tanks and finally, the cost of trucking the oil to market. Relying upon similar cases dealing with natural gas processing, he determined that the deductions claimed were proper in that they were incurred after the wellhead.

The defendants argued that the royalty provision was ambiguous and must be construed against the plaintiffs whose predecessor in interest, Trapper, had drafted the document. They also argued that as a result of the ambiguity, outside evidence was admissible to aid in the construction of the royalty provision and further that the plaintiff was estopped from making the claim to the deductibility of treating costs since no prior operator had sought to make this deduction.

The trial judge found neither a patent nor a latent ambiguity and, accordingly, rejected the defendant's arguments relying on such ambiguity. With respect to the plea of estoppel, he found that there was neither any representation by words or conduct by either the plaintiff or any prior operator and, further, no detrimental reliance on any such representation or conduct on the part of the lessors.

Having found that the costs of treating the oil were deductible, the trial judge proceeded to assess the evidence provided by the plaintiffs to establish the amount of such deductions. In short, the trial judge found that there was not appropriate evidence 
to establish the amount of the deductions and commented in particular that there was no evidence as to the actual costs to the plaintiffs (which should have included evidence on the specific facilities used for gathering, treating and storage, their original capital cost and their current appreciated value). He also indicated that evidence of actual operating costs should have been provided. In the absence of such evidence he felt that the court was left in a state of speculation and conjecture as to quantification of the costs. Although he invited to refer the matter for an assessment, he declined on the basis that the onus was upon the plaintiff to establish the amount of the costs. As the plaintiff failed to do so with reliable evidence, he fixed the costs at one dollar per cubic metre, apparently well below what the plaintiffs had been claiming.

With respect to the defendants' claim that the leases were invalid, the trial judge held that the defendants had not adduced any evidence to establish that the interests had not been validly acquired in the face of the plaintiffs' evidence to establish the chain of title. With respect to the defendants' complaint that the caveats did not set out the full chain of title, Hart J. referred to the decision of Kerans, J.A. in White Resource Management Ltd. v. Durish, ${ }^{70}$ where he stated that while including a detailed history of the interest being claimed on the caveat is the prudent course, it seems not to be required. Furthermore, Hart J. commented that there was no suggestion that any party had been misled by the caveats or relied upon them to their detriment.

\section{COMMENTS}

The case reaffirms the general proposition that the point of valuation of products to compute royalties is governed by the terms of the agreement. It also serves as a reminder to counsel that proof of damages is crucial.
B. IMPERIAL OIL RESOURCES LTD. V. CANADA
(MINISTER OF INDIAN AFFAIRS AND NORTHERN DEVELOPMENT)"

\section{FACTS}

This was a judicial review of a decision of the Minister of Indian Affairs and Northern Development, which confirmed the earlier decision of the Executive Director of Indian Oil and Gas Canada. The matter involved the federal Indian Oil and Gas Regulations, $1995 .^{72}$

Certain Indian bands were entitled to royalties on products of natural gas extracted from certain lands near Bonnie Glen, Alberta, and located on the Pigeon Lake Indian Reserve. During the relevant time under review, Texaco Canada Resources Limited ("TCRL"), predecessor in title to Imperial Oil Resources Ltd. ("Imperial"), was the lessee and operator of the gas producing facility located on the lands. TCRL sold gas products from the facility to an affiliated company, Texaco Canada Incorporated 
("TCl") at the Bonnie Glen plant gate. Pursuant to an agreement between TCRL and TCI, TCI undertook to market gas products acquired from TCRL and to pay TCRL 95 percent of TCl's downstream sale price netted back to the plant (i.e. after deducting transportation and other costs incurred beyond the plant gate). The payment of the 95 percent of TCl's resulting sale price netted back, reflected a 5 percent marketing fee deduction by TCI from the final selling price. Royalties payable to the Indian Bands were calculated on the 95 percent of TCl's selling price netted back to the plant gate.

The Executive Director of Indian Oil and Gas Canada decided that the 5 percent marketing fee should not have been deducted before the calculation of the royalties. As a result, the executive director decided to conduct a formal audit of TCRL and TCI of gas product prices. The applicants appealed this decision to the minister, who confirmed that the director had the right to audit the records of TCRL and TCI. Furthermore, the minister confirmed that the 5 percent marketing fee was improperly deducted and required that the deduction be totally eliminated from the calculation of the royalties.

\section{DECISION}

After reviewing the Regulations, the court indicated that under the agreement between TCI and TCRL, TCI was to sell products downstream of the plant gate, at competitive market value or at prices which could be realized in an arm's-length sale transaction. Deductions from the downstream fair-market-value prices were to be made to establish the price to be received by TCRL at the point of delivery, or the plant gate. These deductions included certain transportation costs and other taxes incurred by TCI and which were imposed on products after the plant gate. TCRL's actual selling price was based on realizing 95 percent of the sale price realized by TCI netted back, to enable TCI to cover its 5 percent marketing fee, transportation, taxation, and other after-plant-gate expenses.

The court noted that the executive director and the minister treated TCRL and TCI as one entity. Under this approach, the executive director and the minister could then treat TCl's downstream selling price as if it were TCRL's actual selling price and the 5 percent marketing fee as if it were an expense of TCRL. They then held that since this was not a cost of processing, it could not be deducted for royalty calculation purposes under the Regulations.

The court indicated that in arm's-length situations TCRL would be entitled to deduct the marketing fee and use the net amount as the actual selling price to form the basis for the calculation of the royalties. The court held that in this situation there was no basis upon which the executive director or the minister could conclude that TCRL and TCI were not arm's-length corporations. There was no evidence in this case that the use of the separate legal entities was being used to defeat the intent and purpose of the Regulations or to convey a false picture of independence between TCRL and TCI. The court also noted that when Parliament intends to treat affiliated corporations as one, it does so expressly. The Regulations contained no such provision in this regard. 
The court held that this decision did not leave a loophole through which royalty allocations could be inappropriately reduced by non-arm's-length dealings. Subsection 21(7) of the Regulations expressly addresses non-arm's-length situations and provides a remedy. Under this section, where the executive director is of the opinion that a sale will be at a price that is less than fair market value, he is authorized to specify the dollar value of the gas that would be realized if it were sold at a fair market value. The lessee must then account for the deficiency between the fair market value and the actual dollar value obtained.

Finally, the court held that there was nothing in the Regulations that permitted the executive director to carry out an audit of TCI and TCRL. The Regulations confer the right of inspection of records in existence only.

\section{COMMENTS}

This decision provides a useful review of the Indian Oil and Gas Regulations, 1995 and the calculation of royalties thereunder.

\section{TAX}

A. IKEA LTD. v. CANADA, ${ }^{73}$ TORONTO COllege PARK LTD. v. CANADA ${ }^{74}$ AND CANDEREL LTD. v. CANADA ${ }^{75}$

\section{COMMENTS}

The issue before the court in these cases was the treatment of tenant improvement payments with respect to their inclusion as income (in the case of Ikea), or as deductions (in the other two cases), for determining taxable income. While the cases do not fall within the scope of decisions usually considered to relate to oil and gas operations, the authors felt that it was worth referring to them for those counsel who are involved in advising clients with respect to income tax matters. The essence of the decisions is that both the payor and the payee have some flexibility in determining how to treat the payment and that the treatment for income tax purposes need not necessarily be the same as for internal accounting purposes.

In the lkea case, the court determined that the payment was received as part of ordinary business operations and was inextricably linked to such operations. Accordingly, no question of linkage to a capital purpose could seriously be entertained and the payment was to be included in income rather than as a capital receipt.

In the other two cases, the developers were entitled to deduct the payments from income in the year they were made, even though not all the benefits related to the expenditure were realized in the year the expenditure was made. 


\section{TORTS}

\section{A. HERCULES MANAGEMENTS LTD. V. ERNST \& YOUNG ${ }^{76}$ \\ 1. FACTS}

Northguard Acceptance Ltd. ("NGA") and Northguard Holdings Ltd. ("NGH") carried on business lending and investing money on the security of real property mortgages. The appellant Guardian Finance of Canada Ltd. ("Guardian") was the sole shareholder of NGH and it held non-voting class B shares in NGA. The appellants Hercules Managements Ltd. ("Hercules") and Max Freed were also shareholders in NGA. At all relevant times, ownership in the corporations was separated from management. The respondent Ernst \& Young was hired by NGA and NGH to perform annual audits of their financial statements and to provide audit reports to the companies' shareholders.

In 1984, both NGA and NGH went into receivership. In 1984, the appellants and a number of other shareholders or investors in NGA brought an action against the respondents alleging that the audit reports for the years 1980, 1981 and 1982 were negligently prepared and that, by relying on these reports, they suffered various financial losses.

The respondents brought a motion for summary judgment in the Manitoba Court of Queen's Bench seeking to have the plaintiffs' claims dismissed on the grounds that the respondent did not owe the individual plaintiffs any duty of care in tort and that the claims asserted by the plaintiffs could only properly be brought by the corporations themselves and not by the shareholders individually. The trial judge granted the motion and the Court of Appeal upheld that decision.

The Supreme Court of Canada stated the issues on appeal as:

(1) do the respondents owe the appellants a duty of care with respect to

(a) the appellants' investment losses incurred allegedly as a result of reliance on the 1980 to 1982 audit reports; and

(b) the losses in the value of their existing shareholdings they incurred allegedly as a result of reliance on the 1980 to 1982 audit reports; and

(2) does the rule in Foss v. Harbottle ${ }^{77}$ (which provides that individual shareholders have no cause of action in law for any wrongs done to the corporation) affect the appellants' action? 


\section{DECISION}

The Supreme Court of Canada dismissed the appeal. After dealing with a number of preliminary matters, the court confirmed that the existence of a duty of care in tort is to be determined through an application of the two-part test enunciated in Anns v. Merton London Borough Council, ${ }^{78}$ and applied in Kamloops (City of) v. Nielsen. ${ }^{79}$ Therefore, whether the respondent auditors owed the appellants a duty of care for their allegedly negligent preparation of the audit reports depended on (1) whether a prima facie duty of care was owed, and (2) whether that duty, if it existed, was negated or limited by policy considerations.

The first branch of the test demands an enquiry into whether there is a sufficiently close relationship between the plaintiff and defendant to ascertain whether, in the reasonable contemplation of the latter, carelessness on its part might cause damage to the plaintiff. In the context of a negligent misrepresentation action, deciding whether a prima facie duty of care exists necessitates an investigation into whether the defendant-representor and the plaintiff-representee can be said to be in a relationship of "proximity" or "neighbourhood." "Proximity" in negligent misrepresentation cases pertains to some aspect of the relationship of reliance. It occurs when (1) the defendant ought reasonably to foresee that the plaintiff will rely on his or her representation; and (2) reliance by the plaintiff would, in the circumstances of the case, be reasonable. In this respect, while specific enquiries into the reasonableness of the plaintiff's expectations are not normally required in the context of physical damage cases (since the law has come to recognize implicitly that it is reasonable for plaintiffs to expect that defendants will take reasonable care of their persons and property), such an enquiry is necessary in the negligent misrepresentation context, because reliance by a plaintiff on a defendant's representation will not always be reasonable.

Tuming to the second part of the Anns/Kamloops test, enquiries concerning the defendant's knowledge of the identity of the plaintiff or class of plaintiffs and the use to which the statements at issue are put properly fall within this part of the test when deciding whether policy considerations ought to negate or limit a prima facie duty that has been found to exist. The fundamental policy consideration that must be addressed in negligent misrepresentation actions centres around the possibility that the defendant might be exposed to "liability in an indeterminate amount for an indeterminate time to an indeterminate class." In the general area of auditors' liability, the problem of indeterminate liability will often arise because the reasonable foreseeability/reasonable reliance test for ascertaining a prima facie duty of care may be satisfied in many, even if not all, such cases.

The court stated that in this case the respondent clearly owed a prima facie duty of care to the appellants. The possibility that the appellants would rely on the audited financial statements in conducting their affairs and that they might suffer harm if the reports were negligently prepared was reasonably foreseeable. Furthermore, reliance on 
the audited statements by the appellant shareholders would be reasonable, given both the relationship between the parties and the nature of the statements themselves.

With respect to the second branch of the Anns/Kamloops test, it was clear that the respondent knew the identity of the appellants when they provided the audit reports. Therefore, the court had to determine whether the appellants could be said to have used the audit reports for the specific purpose for which they were prepared. This answer would determine whether policy considerations surrounding indeterminate liability ought to negate the prima facie duty of care owed by the respondent.

The court found that the auditor's purpose in preparing the reports was to assist the collectivity of shareholders of the audited companies in their task of overseeing management. The respondent did not prepare the audit reports in order to assist the appellants in making personal investment decisions for any purpose other than the standard statutory one. The only purpose for which the reports could have been used so as to give rise to a duty of care on the part of the respondent, therefore, was as a guide for the shareholders, as a group, in supervising or overseeing management.

The appellants claimed that they relied on the respondent's audit reports for the purpose of making individual investments. The court held that since this was not a purpose for which the reports were prepared, this claim must fail. Similarly, the appellants' claim regarding the devaluation of their existing equity caused by the appellants' alleged inability to oversee personal investments must fail since monitoring existing personal investments is not a purpose for which the audited statements were prepared.

With respect to the appellants' claim relating to the devaluation of their equity because they could not properly supervise management with a view to protecting their personal holdings, the court noted that this position may at first seem consistent with the purpose for which the reports were prepared. In reality, however, their claim did not involve the purpose of overseeing management per se. Rather, it ultimately depended on being able to use the auditors' reports for the individual purpose of overseeing their own investments. Thus, the purpose for which the reports were used was not, in fact, consistent with the purpose for which they were prepared. The prima facie duty of care was negated by policy considerations and, therefore, no duty of care was owed by the respondents in this regard.

The absence of a duty of care with respect to the appellant's alleged inability to supervise management in order to monitor their individual investments is consistent with the rule in Foss v. Harbottle, which provides that individual shareholders have no cause of action for wrongs done to the corporation. When, as a collectivity, shareholders oversee the activities of a corporation through resolutions adopted at shareholder meetings, they assume a "managerial" role. In this capacity, they cannot properly be understood to be acting simply as individual holders of equity. Rather, their collective decisions are made in respect of the corporation itself. As such, any duty owed by auditors in respect of this aspect of the shareholders' functions is owed to all shareholders as a group, acting in the interests of the corporation. A derivative action 
would have been the proper method of proceeding with respect to a claim for reliance on negligently prepared audit reports which have wronged the corporation.

\section{COMMENTS}

The Supreme Court of Canada upheld the traditional general rule that accountants who perform audits of a corporation's financial statements do not owe a duty of care in tort to shareholders of the corporation who claim to have suffered losses in reliance on the audited statements. The court also held that claims against auditors are properly brought by the corporation in the form of a derivative action as opposed to shareholders as individuals.

\section{B. BOW VALLEY HUSKY (BERMUDA) LTD. V. SAINT JOHN SHIPBUILDING ${ }^{80}$}

\section{FACTS}

In 1987, a fire broke out on a drilling rig which was drilling for oil on the Grand Banks of Newfoundland. The rig sustained major damage and extensive repairs were required. The companies which had contracted for the lease of the rig suffered financial loss while it was out of commission. The issue in this appeal was the legal responsibility for the damages and the extent of the damages recoverable. The Supreme Court of Canada also dealt with the applicability of contributory negligence principles under Canadian maritime law and the recovery of damages for contractual relational economic loss.

Husky Oil Operations Ltd. ("HOOL") and Bow Valley Industries Ltd. ("BVI") purchased an oil rig and made arrangements to have two others built. To this end, a subsidiary of BVI contracted with Saint John Shipbuilding Limited ("SJSL") for the construction of a drilling rig, which was the one that ultimately sustained damage as a result of the fire. To take advantage of government financing, HOOL and BVI incorporated an offshore company, Bow Valley Husky (Bermuda) Ltd. ("BVHB"). Ownership of the rig which was to be constructed by SJSL was transferred to BVHB, and the contract with SJSL for the construction of the rig was assigned to BVHB. HOOL and BVI entered into contracts with BVHB to hire the rig to conduct drilling operations. These contracts provided that $\mathrm{HOOL}$ and BVI were to pay day rates to BVHB in the event that the rig was out of service.

Using BVHB's specifications, an independent manufacturer built a heat trace system and SJSL built this into the rig. This system used Thermaclad wrap to keep moisture from the wires. The specifications for the manufacturer's system required a ground fault circuit-breaker be installed which was to cut off the power in the event of an electrical fault and to prevent arcing of the heat trace wire. Such a circuit-breaker, however, was never installed. 
The rig was put out of service for several months after the fire broke out. BVHB, HOOL and BVI brought actions for negligence and breach of contract against SJSL, and for negligence against the manufacturer of the heat trace system. BVHB claimed the cost of repairing the rig and consequential lost revenue while it was out of service. HOOL and BVI claimed for the day rates they were contractually obligated to pay while the rig was out of service.

The trial judge held that SJSL and the manufacturer were negligent but that BVHB was 60 percent contributorily negligent for the loss as well, primarily because BVHB failed to install a proper ground fault circuit-breaker. However, the court held that maritime law applied to this case, which provided that contributory negligence bars a plaintiff's recovery. As such, all of the plaintiffs' claims were dismissed. The Newfoundland Court of Appeal held that the Newfoundland Contributory Negligence $A c t^{81}$ applied and BVHB would therefore recover 40 percent of its loss. Alternatively, the Court of Appeal held that maritime law no longer made contributory negligence a complete bar to recovery. With respect to the HOOL and BVI claim, the Court of Appeal held that their claims were dismissed because their losses were purely economic. BVI and HOOL appealed and SJSL and the manufacturer cross-appealed to the Supreme Court of Canada.

\section{DECISION}

The Supreme Court of Canada dismissed the appeal and allowed the cross-appeal. With respect to BVI and HOOL's appeal, the court held that the losses were for contractual relational economic loss and therefore could be recovered only in special circumstances, which are:

(1) cases where the claimant has a possessory or proprietary interest in the damaged property;

(2) general average cases; and

(3) cases where the relationship between the claimant and property owner constitutes a joint venture.

The claims in this case did not fall into any such category. The court did indicate, however, that new categories may be recognized in the future.

As in the Hercules decision, ${ }^{82}$ the court outlined the two-step test for when recovery is available (following Anns v. Merton London Borough Council, ${ }^{83}$ and Kamloops (City of v. Nielsen ${ }^{84}$ ). The first step is to inquire whether a relationship of neighbourhood or proximity necessary to find a prima facie duty of care exists. It was 
present in this case. The second step is to inquire whether the policy concerns that usually preclude recovery of contractual relational economic loss, such as indeterminacy, were overridden. In this case, they were not.

With respect to the maritime law and contributory negligence issue, the court held that, while at common law (Maritime law) contributory negligence was a complete bar to recovery, courts may change the law by extending existing principles where the change is clearly necessary to keep the law in step with the "dynamic and evolving fabric of our society" and the ramifications of the change is not incapable of assessment. In this case it was appropriate to make a change to the common law because the considerations on which the contributory negligence bar was based were no longer consistent with the modern view of fairness and justice. The principle of apportionment for non-maritime torts was universally accepted and lifting the bar to recovery would bring the law in step not only with "the changing social, moral and economic fabric of the country," but also with the law of other jurisdictions. Accordingly, the manufacturer and SJSL were held jointly and severally liable to BVHB for $\mathbf{4 0}$ percent of its loss.

With respect to SJSL's cross-appeal, the court held that SJSL was not liable for breach of a duty to warn because such a duty was precluded by the contract between it and BVHB. The court noted that where an owner specifies a particular product be used, it was generally the owner and not the builder who, unless otherwise specified in the contract, should bear the losses associated with that product's use. In this case, however, the contract precluded the owner's liability.

\section{COMMENTS}

The Supreme Court of Canada's discussion of the principles upon which damages for contractual relational economic loss can be recovered should be useful to those dealing with such issues. One of the more interesting aspects in this case is the court's decision to change the common law so that a plaintiff's recovery is not barred on the basis of the plaintiff's contributory negligence.

C. NORMART MANAGEMENT LTD. V. WEST HILL REDEVELOPMENT CO. ${ }^{85}$

See the discussion set out at VI.A. 


\section{TRUSTS}

\section{A. SOULOS V. KORKONTZILAS \\ 1. FACTS}

The Supreme Court of Canada stated that this appeal required the court to determine whether a real estate agent who buys, as principal, property for which he had been negotiating on behalf of his client, may be required to return the property to his client despite the fact that the client can show no loss. This raises the legal issue of whether a constructive trust over property may be imposed in the absence of enrichment of the defendant and corresponding deprivation of the plaintiff.

\section{DECISION}

The court answered the question in the affirmative (Sopinka and lacobucci JJ. dissent). The court held that the constructive trust is an institution imposed by law not only to remedy unjust enrichment, but to hold persons in different situations to high standards of trust and probity and prevent them from retaining property which in "good conscience" they should not be permitted to retain. Canadian courts in recent decades have developed the constructive trust as a remedy for unjust enrichment. However, the constructive trust is still available in other circumstances and under the broad umbrella of good conscience, constructive trusts are recognized both for wrongful acts like fraud and breach of duty of loyalty, and to remedy unjust enrichment and corresponding deprivation. While cases often involve both a wrongful act and unjust enrichment, constructive trusts may be imposed on either ground.

The court held that the following conditions should generally be satisfied before a constructive trust based on wrongful conduct will be imposed:

(1) the defendant must have been under an equitable obligation in relation to the activities giving rise to the assets in his hands;

(2) the assets in the hands of the defendant must be shown to have resulted from deemed or actual agency activities of the defendant in breach of his equitable obligation to the plaintiff;

(3) the plaintiff must show a legitimate reason for seeking a proprietary remedy, either personal or related to the need to ensure that others like the defendant remain faithful to their duties; and

(4) there must be no factors which would render imposition of a constructive trust unjust in all the circumstances of the case. 
Here, the real estate agent's breach of his duty of loyalty sufficed to engage the conscience of the court and support a finding of constructive trust. A constructive trust is also required in cases such as this to ensure that agents and others in positions of trust remain faithful to their duty of loyalty.

\section{COMMENTS}

Canadian courts in recent decades have used constructive trusts almost exclusively as a remedy for unjust enrichment. The court in this case reaffirms the traditional principles upon which constructive trusts were originally based. Accordingly, the "good conscience" basis is wider than the "unjust enrichment" basis and, in the former cases, no "enrichment" is required. 